Jurnal Ilmu Ilmu Agribisnis: Journal of Agribusiness Science, 9(4), November 2021

\title{
ANALISIS BAURAN PEMASARAN (Marketing Mix) KERIPIK PISANG DI SENTRA INDUSTRI KERIPIK KOTA BANDAR LAMPUNG
}

\author{
(Marketing Mix of Banana Chips at The Industrial Chip Center in Bandar Lampung)
}

Erinda Pradini, Dwi Haryono, Yaktiworo Indriani

\begin{abstract}
Jurusan Agribisnis, Fakultas Pertanian, Universitas Lampung, Jl. Prof. Dr. Soemantri Brojonegoro No. 1, Bandar Lampung 35145, Telp.08996430324,e-mail: dwi.haryono@fp.unila.ac.id
\end{abstract}

\begin{abstract}
This study aims to analyze the marketing mix applied on the marketing activities and study the obstacles onapplying marketing mix, in addition to analyzing the marketing mix that should be carried out by banana agroindustry of "Askha Jaya Keripik Lampung". This research was a case study conducted in January to February 2020 at the Bandar Lampung Industrial Chip Center in which data was analyzed by qualitative descriptive analysis method. The results of this study showed that the marketing mix carried out by Askha Jaya Agroindustry produced three types of banana chips, namely sliced, rounded and melted. The determination of the selling price was implemented by the cost plus pricing method. The distribution channels were conducted by two channels and promotions was carried out through personal selling, sales promotion, advertising and publicity. Some constraints faced by the agroindustry were the availability of products caused by the scarcity of raw materials, delaying in the process of services to consumers, product delivering time and imaging capture without permission on online marketing. The marketing mix that should be done was reducing the size of the product weight when there was scarcity of raw materials, adding price tags to the shop, and the need of sanctions for those who were not responsible for online marketing.
\end{abstract}

Keywords: agroindustry, banana chips, marketing mix

Received: 31 August $2020 \quad$ Revised: 5 October 2020 Accepted:1 April 2021 DOI: http://dx.doi.org/10.23960/jiia.v9i4.5407

\section{PENDAHULUAN}

Sektor pertanian berpengaruh penting terhadap pembangunan nasional, karena Indonesia memiliki sumber daya alam melimpah. Selain itu, juga berperan sebagai sumber penghasil devisa negara, penyedia bahan baku industri pertanian, hingga sebagai sumber tenaga kerja, terutama komoditas tanaman hortikultura. Direktorat Jenderal Hortikultura (2020) mengupayakan beberapa kebijakan diantaranya menjaga kestabilan harga, menurunkan konsumsi impor dan mendorong ekspor komoditas hortikultura.

Berdasarkan (BPS 2018), subsektor hortikultura merupakan salah satu subsektor pertanian yang menyumbang 23,81 persen dalam laju pertumbuhan Produk Domestik Bruto. Selain itu tanaman hortikultura memiliki puluhan jenis komoditas potensial untuk dikembangkan sebagai sentra bisnis. Subsektor holtikultura setiap tahun mengalami pertumbuhan produksi.

Tanaman pisang memiliki laju pertumbuhan produksi sebesar 1,42 persen dengan produksi terbesar yaitu 7,26 juta ton pada tahun 2018 (BPS 2018 dan Direktorat Jenderal Hortikultura 2018). Pisang merupakan salah satu buah populer di masyarakat, karena tersedia dalam berbagai jenis, harga terjangkau, mudah ditemukan, dan memiliki kandungan vitamin serta mineral bermanfaat bagi kesehatan. Perkembangan produksi tanaman pisang sangat dibutuhkan untuk menunjang pembangunan ekonomi Indonesia. Daerah penghasil pisang terbesar di Indonesia yaitu Provinsi Jawa Timur dengan jumlah produksi sebesar 2,05 juta ton. Produksi terbesar kedua berada di daerah Provinsi Lampung dengan jumlah produksi 1,43 juta ton (BPS 2018).

Pisang dimanfaatkan sebagai produk perdagangan unggulan khas Provinsi Lampung selain kopi dan lada. Pemanfaatan olahan pisang ini mendukung pengembangan usaha kuliner khususnya di Kota Bandar Lampung dan menopang perekonomian Provinsi Lampung. Keripik pisang merupakan salah satu primadona oleh-oleh khas Lampung yang memiliki kelebihan rasa beragam dan bentuk yang unik. Produk ini sangat menarik minat konsumen dengan pemberian aneka rasa dan 


\section{Jurnal Ilmu Ilmu Agribisnis: Journal of Agribusiness Science, 9(4), November 2021}

mengalami permintaan yang tinggi, sehingga mengakibatkan banyak agroindustri yang Dalam upaya dalam mempertahankan kelangsungan usaha agroindustri harus memiliki strategi dalam menciptakan keunggulan produk agar konsumen tidak beralih ke produk agroindustri lain, khususnya di Kota Bandar Lampung dengan menganalisis bauran pemasaran berupa aspek produk, harga, tempat dan promosi. Bauran pemasaran yang efektif dapat membantu pelaku usaha dalam memasarkan produknya kepada konsumen.

Salah satu pelaku usaha keripik pisang yang ada di Sentra Industri Keripik Kota Bandar Lampung adalah Askha Jaya. Agroindustri ini cenderung bersaing dengan agroindustri lain yang sejenis. Tentu saja agroindustri harus mengetahui bauran pemasaran untuk dapat meningkatkan volume penjualan. Selain itu diperlukan bauran pemasaran yang tepat untuk diterapkan dalam menghadapi kendala-kendala perusahaan dalam memasarkan produk agar mampu meningkatkan penjualan agroindustri Askha Jaya.

Berdasarkan uraian tersebut, maka analisis bauran pemasaran di Agroindustri Askha Jaya penting dilakukan. Pengusaha perlu mengetahui bagaimana bauran pemasaran yang tepat untuk diterapkan agar dapat mempertahankan konsumen atau pelanggan, sehingga memperoleh keuntungan maksimal (Kotler 2002). Tujuan penelitian ini menganalisis bauran pemasaran yang diterapkan dalam kegiatan pemasaran keripik pisang, mempelajari kendala-kendala yang dihadapi agroindustri dan menganalisis bauran pemasaran yang sebaiknya dilakukan pada agroindustri.

\section{METODE PENELITIAN}

Penelitian ini merupakan studi kasus yang dilaksanakan pada Agroindustri Askha Jaya di sentra industri keripik Kota Bandar Lampung yang memiliki empat outlet penjualan. Pemilihan lokasi dilakukan secara sengaja (purposive), dengan pertimbangan bahwa agroindustri merupakan salah satu agroindustri terbesar dan namanya sudah dikenal baik di tingkat nasional maupun internasional. Waktu pengumpulan data dilakukan pada bulan Januari 2020 - Februari 2020.

Pemilihan responden dalam penelitian ini menggunakan metode purposive sampling, yaitu pemilihan anggota sampling yang ditentukan secara sengaja berdasarkan atas tugas dan tanggung jawab responden (Mustafa 2000). bermunculan dan terjadi persaingan penjualan produk keripik pisang.

Responden pada penelitian ini sebanyak 57 orang yaitu, satu orang pemilik, tiga orang karyawan bidang pemasaran, tiga orang pemilik agroindustri pesaing dan 50 orang konsumen agroindustri Askha Jaya yang ditemui secara sengaja saat berbelanja yang merupakan konsumen sekaligus responden. Penentuan ukuran sampel penelitian sesuai pernyataan Roscoe (1982) dalam Sugiyono (2011) yaitu ukuran sampel yang layak dalam penelitian antara 30 sampai dengan 500 responden.

Data primer penelitian diperoleh dari wawancara menggunakan kuisioner, pengamatan serta pencacatan langsung tentang keadaan di lokasi penelitian. Adapun data sekunder diperoleh dari studi literatur, publikasi dan pustaka lainnya, serta lembaga/instansi terkait dalam penelitian.

Data dianalisis secara deskriptif kualitatif. Analisis deskriptif kualitatif digunakan untuk menganalisis bauran pemasaran, kendala-kendala dan bauran pemasaran yang sebaiknya diterapkan agroindustri. Analisis bauran pemasaran dilakukan untuk melihat strategi penjualan yang dilihat dari variabel-variabel yang sering disebut $4 \mathrm{P}$, yaitu produk (product), harga (price), tempat (place) dan promosi (promotion) dengan metode wawancara dengan responden Agroindustri Askha Jaya menggunakan dua perspektif, yaitu perspektif pemilik agroindustri dan perspektif konsumen.

Pengumpulan data primer pada analisis bauran pemasaran perspektif pemilik agroindustri menggunakan kuesioner terbuka dan tertutup melalui wawancara dengan pemilik agroindustri dan karyawan. Pengumpulan data primer pada analisis bauran pemasaran perspektif konsumen menggunakan kuesioner tertutup yang diukur berdasarkan skala likert yang terdiri dari 23 pertanyaan. Penilaian dalam skala likert terdiri dari lima kriteria skor yaitu "1" untuk tidak baik, " 2 " untuk kurang baik, " 3 " untuk cukup, " 4 " untuk baik, dan " 5 " untuk sangat baik. Uji validitas dan reliabilitas kuesioner tersebut dilakukan terhadap 30 responden.

Validitas memiliki arti ketepatan dan kecermatan suatu instrumen atau alat ukur dalam melakukan fungsi ukur. Instrumen dapat dikatakan memiliki validitas yang tinggi apabila fungsi ukur telah sesuai dengan maksud dilakukannya pengukuran. Oleh karena itu, kuesioner sebagai alat ukur yang digunakan dalam penelitian ini harus dinyatakan valid (Sugiyono 2010). 
Uji reliabilitas merupakan pengujian terhadap kuesioner penelitian yang digunakan untuk mengetahui apakah kuesioner tersebut reliable atau tidak (Sufren dan Natanael 2014). Uji reliabilitas dapat digunakan menggunakan rumus sebagai berikut:

$$
\mathrm{r}=\left[\frac{\mathrm{k}}{(\mathrm{k}-1)}\right]\left[1-\frac{\sum_{\sigma \mathrm{b}} 2}{\sigma \mathrm{t}^{2}}\right]
$$

Keterangan:

$$
\begin{array}{ll}
\mathrm{r} & =\text { koefisien reliability instrument } \\
\mathrm{k} & =\text { banyaknya butir pertanyaan } \\
\sum \sigma \mathrm{b} 2 & =\text { total varians butir } \\
\sigma \mathrm{t} 2 & =\text { total varians }
\end{array}
$$

Untuk mengukur reliabilitas yaitu melalui uji statistik cronbach alpha dan variabel dikatakan reliabel jika nilai cronbach alpha $>\mathrm{r}$ tabel. Nilai $\mathrm{r}$ tabel yang digunakan adalah 0,60. Hasil uji validitas dan reliabilitas kuesioner dengan bantuan program SPSS disajikan pada Tabel 1. Berdasarkan hasil uji validitas dari 23 pertanyaan diperoleh nilai corrected item total correlation di

\begin{tabular}{|c|c|c|c|c|c|}
\hline \multirow{2}{*}{ No } & \multirow{2}{*}{ Atribut } & \multicolumn{2}{|c|}{ Uji Validitas } & \multicolumn{2}{|c|}{ Uji Reliabilitas } \\
\hline & & Nilai & Hasil & Nilai & Hasil \\
\hline \multicolumn{6}{|c|}{ Product (Produk) } \\
\hline & Kualitas & 0,664 & Valid & 0,905 & Reliabel \\
\hline & Kuantitas & 0,519 & Valid & & \\
\hline & Tampilan & 0,381 & Valid & & \\
\hline & Pengemasan & 0,450 & Valid & & \\
\hline & Cap (merk) & 0,403 & Valid & & \\
\hline & Rasa & 0,549 & Valid & & \\
\hline & Keawetan & 0,562 & Valid & & \\
\hline \multicolumn{6}{|c|}{ Price (Harga) } \\
\hline & Terjangkau & 0,580 & Valid & & \\
\hline & Sesuaiharapan & 0,641 & Valid & & \\
\hline & Relatif murah & 0,654 & Valid & & \\
\hline 11 & Potongan harga & 0,536 & Valid & & \\
\hline 12 & Pembayaran & 0,380 & Valid & & \\
\hline \multicolumn{6}{|c|}{ Place (Tempat) } \\
\hline 13 & Strategis & 0,485 & Valid & & \\
\hline & $\begin{array}{l}\text { Berdekatan toko } \\
\text { sejenis }\end{array}$ & 0,468 & Valid & & \\
\hline & $\begin{array}{l}\text { Jangkauan } \\
\text { transportasi }\end{array}$ & 0,526 & Valid & & \\
\hline 16 & Kenyamanan & 0,484 & Valid & & \\
\hline 17 & Jasa pesan antar & 0,743 & Valid & & \\
\hline 18 & Distribusi produk & 0,682 & Valid & & \\
\hline \multicolumn{6}{|c|}{ Promotion (Promosi) } \\
\hline 19 & Kegencaran promosi & 0,811 & Valid & & \\
\hline 20 & Membantukonsumen & 0,779 & Valid & & \\
\hline 21 & Menarik & 0,563 & Valid & & \\
\hline 22 & Sesuai kenyataan & 0,672 & Valid & & \\
\hline 23 & Media bervariasi & 0,622 & Valid & & \\
\hline
\end{tabular}
atas 0,20 . Hal ini menyatakan 23 pertanyaan

Tabel 1. Hasil uji validitas dan reliabilitas bauran pemasaran berdasarkan perspektif konsumen agroindustri Askha Jaya, 2020 tersebut valid yakni atribut yang diukur sesuai dengan variabel yang hendak diteliti. Uji reliabilitas diperoleh nilai cronbach alpha sebesar 0,905 . Hal ini menunjukkan bahwa nilai reliabel lebih besar dari 0,60 sehingga atribut pertanyaan dapat dinyatakan reliabel yakni jawaban responden yang diperoleh dari uji kuesioner cenderung stabil atau konsisten. Jadi, berdasarkan uji validitas dan reliabilitas kuesioner bauran pemasaran perspektif konsumen dinyatakan valid dan reliabel, maka kuesioner dapat digunakan untuk penelitian ini.

Analisis deskriptif kualitatif digunakan untuk menjawab tujuan pertama yaitu menganalisis bauran pemasaran yang diterapkan dalam kegiatan pemasaran keripik pisang pada agroindustri melalui perspektif pemilik dan konsumen. Bauran pemasaran berdasarkan perspektif pemilik dianalisis sesuai dengan keadaan nyata yang ada pada agroindustri, sedangkan perspektif konsumen dianalisis dengan tanggapan konsumen terhadap agroindustri melalui hasil persentase skor skala likert yang diperoleh dari perhitungan sebagai berikut.

$$
\mathrm{p}=\frac{\mathrm{f}}{\mathrm{n}} \times 100 \%
$$

\section{Keterangan:}

$\mathrm{p} \quad=$ persentase

$\mathrm{f} \quad=$ frekuensi dari setiap jawaban

$\mathrm{n} \quad=$ jumlah skor ideal

$100=$ bilangan tetap

Analisis deskriptif kualitatif juga digunakan untuk jawaban dari tujuan ke dua yaitu mempelajari kendala-kendala yang dihadapi agroindustri dan perspektif konsumen terhadap agroindustri maka analisis bauran pemasaran yang sebaiknya diterapkan akan terjawab.

\section{HASIL DAN PEMBAHASAN}

\section{Karakteristik Responden}

Karakteristik responden dalam penelitian ini dilihat berdasarkan beberapa aspek, yaitu tingkat pendidikan, umur, jenis kelamin, pendapatan dan pekerjaan. Responden berada di usia produktif, baik pemilik, karyawan, pesaing, maupun konsumen. Umur responden pemilik, karyawan dan pesaing agroindustri bervariasi antara 18-54 tahun, sehingga dapat dikatakan bahwa responden pada agroindustri Askha Jaya termasuk dalam klasifikasi umur produktif. Berdasarkan jenis kelamin didominasi oleh laki-laki sebesar 72 
persen. Tingkat pendidikan bervariasi antara SLTA hingga S2, hal ini menyebabkan mudahnya kemampuan yang dimiliki dalam menerima, menyerap serta menerapkan teknologi dalam mengembangkan agroindustri.

Umur responden konsumen berkisar antara 15-51 tahun. Menurut (Mantra 2004), usia produktif penduduk berada pada kisaran 15-64 tahun, maka seluruh responden penelitian berada pada usia produktif. Jenis kelamin responden konsumen didominasi oleh perempuan sebesar 70 persen. Tingkat pendidikan responden konsumen didominasi oleh SLTA sebesar 44 persen. Konsumen yang memiliki pekerjaan Pegawai Swasta mendominasi sebesar 32 persen dengan kisaran pendapatan Rp2.000.001,00Rp3.000.000,00 sebanyak 17 orang (34\%). Hal ini berbeda dengan penelitian Indriastuti, Affandi dan Indriani (2015) yang mengungkapkan bahwa tingkat pendidikan konsumen keripik pisang didominasi oleh Sarjana dan pekerjaan konsumen didominasi oleh Pegawai Negeri Sipil.

Berdasarkan jenis kelamin, umur, dan tingkat pendidikan konsumen memiliki peluang yang samadalam mengonsumsi keripik pisang karena dapat berpikir baik dalam memilih produk. Akan tetapi, jika dilihat dari pendapatan/uang saku, responden konsumen akan membeli produk bergantung akan pendapatan mereka, dikarenakan semakin besar pendapatan maka kuantitas produk keripik pisang yang dibeli oleh konsumen juga semakin besar.

\section{Bauran Pemasaran Agroindustri Askha Jaya Perspektif Pemilik}

Bauran pemasaran produk keripik pisang dalam penelitian ini menggunakan dua perspektif, yaitu perspektif pemilik agroindustri dan perspektif konsumen. Bauran pemasaran bagi pemilik agroindustri sangat penting dalam menunjang kelangsungan usahanya. Unsur produk bagi pemilik sebagai usaha yang dilakukan untuk pengembangan dan pemasaran keripik pisang, sehingga produk dapat memuaskan konsumen sekaligus memberikan keuntungan pada agroindustri. Harga bagi pemilik yaitu, menetapkan harga yang pantas, terjangkau dan tidak merugikan agroindustri. Tempat dan promosi bagi pemilik sebagai sarana menyampaikan produk kepada konsumen dengan efektif dan efisien agar meningkatkan penjualan agroindustri yang dapat dilihat pada Tabel 2 .

Tabel 2. Komponen bauran pemasaran berdasarkan perspektif pemilik agroindustri Askha Jaya, 2020

\begin{tabular}{|c|c|c|}
\hline & Komponen & Pelaksanaan di Agroindustri \\
\hline \multicolumn{3}{|c|}{ Produk } \\
\hline 1 & $\begin{array}{l}\text { Bentuk, ukuran, dan jumlah produksi } \\
\text { keripik pisang }\end{array}$ & Kualitas dan kuantitas sesuai dengan permintaan konsumen \\
\hline 2 & Bentuk kemasan & Kemasan beragam dari ekonomis hingga premium \\
\hline 3 & Merek & Sudah memiliki merek dagang \\
\hline 4 & Keawetan & 3 bulan \\
\hline \multicolumn{3}{|c|}{ Harga } \\
\hline 5 & Penetapan harga & Berdasarkan biaya produksi keripik pisang \\
\hline 6 & Harga keripik pisang & Terjangkau \\
\hline 7 & Cara pembayaran & Tunai \\
\hline \multicolumn{3}{|c|}{ Tempat } \\
\hline 8 & Penjualan keripik pisang & $\begin{array}{l}\text { Dipasarkan secara langsung, media sosial serta melalui perantara distributor dan } \\
\text { pedagang pengecer (reseller) }\end{array}$ \\
\hline 9 & Sasaran pemasaran & Masyarakat umum \\
\hline 10 & Lokasi pemasaran & $\begin{array}{l}\text { Sentral Industri Keripik Kota Bandar Lampung, pedagang pengecer (reseller) di } \\
\text { seluruh Indonesia dan pemasaran online (Shopee, Bukalapak, Tokopedia, Go-food } \\
\text { dan Grab-food) }\end{array}$ \\
\hline 11 & Lokasi agroindustry & Strategis \\
\hline \multicolumn{3}{|c|}{ Promosi } \\
\hline 12 & Periklanan & Sosial media Instagram, Facebook, Shopee, Bukalapak dan lain-lain \\
\hline 13 & Penjualan tatap muka & 4 outlet penjualan di Sentra Industri Keripik Kota Bandar Lampung \\
\hline 14 & Publisitas & Koran \\
\hline 15 & Promosi penjualan & Pemberian potongan harga, pemberian bonus produk dan pameran tahunan \\
\hline
\end{tabular}


Data pada Tabel 2 menunjukkan bahwa komponen bauran pemasaran berdasarkan perspektif pemilik sudah diterapkan dengan baik. Produk yang dihasilkan berupa keripik pisang dengan 21 varian rasa, terdiri dari tiga jenis keripik dan dikemas dalam kemasan berbeda-beda, sesuai dengan permintaan konsumen. Kemasan sudah diberi merk dagang dan label halal, sehingga konsumen merasa aman ketika mengkonsumsi produk. Merek dagang yang dimiliki mudah dieja, dibaca, diingat, enak didengar dan tidak memberikan kesan negatif. Bahan baku dan bahan pelengkap yang digunakan memiliki kualitas yang baik, sehingga berpengaruh terhadap keawetan dan kualitas produk. Hal ini sejalan dengan Akbar, Lestari dan Nugraha (2020) yang mengungkapkan bahwa komponen produk yang terdiri dari bentuk, ukuran, dan jumlah produksi kopi bubuk pada Agroindustri KBCOML telah disesuaikan dengan permintaan konsumen.

Penetapan harga produk berdasarkan biaya produksi yang dikeluarkan, hal tersebut dimaksudkan besar kecil biaya yang dikeluarkan akan mempengaruhi harga jual produk keripik pisang. Penambahan laba sebesar 10 persen-20 persen dari biaya total. Namun, laba diperoleh bergantung keadaan agroindustri, apabila bahan baku mengalami kelangkaan akan mengakibatkan perubahan harga jual produk. Harga jual produk kepada konsumen yaitu sebesar Rp50.000,00 per kilogram pada keadaan normal dan pada saat kelangkaan bahan baku harga produk akan naik menjadi Rp70.000,00 per kg. Harga jual produk kepada pengecer (reseller) selisih Rp5.000,00 dari harga jual pada konsumen. Cara pembayaran secara tunai dipilih guna meminimalisir terjadinya kerugian. Hal ini berbeda dengan penelitian Epriani, Endaryanto, dan Indriani (2017) mengungkapkan bahwa metode penetapan harga Kopi Bubuk Cap Intan pada konsumen adalah metode berdasarkan harga pesaing.

Penjualan keripik pisang dipasarkan melalui dua saluran distribusi, yaitu pertama produsen menjual kepada konsumen akhir melalui pemasaran langsung di outlet penjualan dan kedua, produsen menjual kepada reseller yang kemudian dijual kepada konsumen akhir. Lokasi pemasaran berada di Sentra Industri Keripik Kota Bandar Lampung dengan empat outlet penjualan dan agroindustri Askha Jaya juga memasarkan produknya pada pemasaran online melalui reseller yang ada di seluruh Indonesia. Hal ini dimaksudkan agar produk tersebar ke kalangan masyarakat yang berada diberbagai daerah. Kerjasama juga dilakukan dengan jasa pengiriman seperti JNE, strategi ini dilakukan untuk mempermudah konsumen dalam memperoleh produk. Hal ini tak sejalan dengan penelitian Putri, Affandi, dan Nikmatullah (2020) yang mengungkapkan bahwa Kopi Bubuk Cap J hanya dipasarkan melalui toko dan pasar tradisional serta sasaran pemasaran agroindustri hanya masyarakat daerah Provinsi Lampung khususnya di Kota Bandar Lampung.

Promosi yang dilakukan oleh melalui periklanan dengan memanfaatkan teknologi media sosial seperti Instagram, Tokopedia dan Whats-App. Teknologi dimanfaatkan untuk memperluas dan mempermudah konsumen dalam pembelian produk keripik pisang. Promosi dengan penjualan tatap muka melalui lokasi penjualan dan cabang penjualan agroindustri juga dilakukan untuk merangsang pembelian. Publisitas pernah dilakukan melalui media koran pada awal membangun usaha. Promosi penjualan lainnya yaitu pemberian potongan harga kepada konsumen dengan pembelian minimal $\mathrm{Rp} 300.000,00$ dan akan diberikan bonus produk. Bonus produk yang diberikan kepada konsumen biasanya adalah emping jagung. Agroindustri juga mengikuti pameran daerah di Provinsi Lampung guna memperkenalkan usahanya pada masyarakat. Secara keseluruhan kegiatan promosi sudah dilakukan agroindustri dengan baik. Hal ini tak sejalan dengan penelitian Ledy, Haryono dan Situmorang (2019) yang mengungkapkan bahwa promosi yang dilakukan oleh agroindustri Kopi Bubuk Cap Intan belum diterapkan secara keseluruhan, hal ini disebabkan kurangnya pengetahuan dalam menggunakan teknologi serta keterbatasan modal yang dimiliki.

\section{Perspektif Konsumen}

Bauran pemasaran berdasarkan perspektif konsumen sangat membantu agroindustri dalam menjalankan usahanya. Produk bagi konsumen menjadi kebutuhan untuk memenuhi kepuasaannya. Harga yaitunilai yang dapat ditukarkan dan memberikan manfaat dari memiliki suatu barang atau jasa dan merupakan hal yang sangat penting untuk dipertimbangkan dalam mengkonsumsi suatu barang atau jasa. Tempat diartikan sebagai tempat dimana konsumen dapat memperoleh produk yang dibutuhkan dan promosi merupakan berbagai kegiatan yang dilakukan untuk menginformasikan produk kepada konsumen agar mengenal dan membeli produk. Komponen bauran pemasaran berdasarkan perspektif konsumen tersebut dapat dilihat pada Tabel 3. 
Tabel 3. Komponen bauran pemasaran berdasarkan perspektif konsumen agroindustri Askha Jaya, 2020

\begin{tabular}{clc}
\hline \multicolumn{1}{c}{ Komponen } & Persentase $(\%)$ \\
\hline \multicolumn{2}{l}{ Produk } & 92,40 \\
\hline 1 & Kualitas & 88,80 \\
2 & Kuantitas & 89,60 \\
3 & Tampilan produk & 92,80 \\
4 & Pengemasan & 92,00 \\
5 & Cap (merek) & 94,00 \\
6 & Rasa & 92,80 \\
7 & Keawetan & 91,77 \\
\hline \multicolumn{2}{l}{ Rata-Rata } \\
\hline Harga & 82,00 \\
\hline 8 & Terjangkau & 81,20 \\
9 & Sesuai harapan & 75,60 \\
10 & Relatif murah & 82,00 \\
11 & Potongan harga & 91,20 \\
12 & Pembayaran & 82,40 \\
\hline \multicolumn{2}{l}{ Rata-Rata } \\
\hline Tempat & 89,20 \\
\hline 13 & Strategis & 92,80 \\
14 & Berdekatan toko sejenis & 94,00 \\
15 & Jangkauan transportasi & 93,20 \\
16 & Kenyamanan & 83,20 \\
17 & Jasa pesan antar & 86,40 \\
18 & Distribusi produk & 89,80 \\
\hline \multicolumn{2}{l}{ Rata-Rata } & 86,40 \\
\hline Promosi & 89,60 \\
\hline 19 & Kegencaran promosi & 88,40 \\
20 & Membantu konsumen & 84,80 \\
21 & Menarik & 86,80 \\
22 & Sesuai kenyataan & 87,20 \\
\hline 23 & Media bervariasi & \\
\hline & Rata-Rata & \\
\hline & & \\
\hline
\end{tabular}

Pada Tabel 3 menunjukkan bahwa komponen bauran pemasaran berdasarkan perspektif konsumen yang berjumlah 50 orang memiliki penilaian dengan baik. Komponen produk yang memiliki persentase terbesar terdapat pada rasa yaitu 94,00 persen, yang menunjukkan bahwa produk keripik pisang memiliki cita rasa yang lezat. Komponen harga yang memiliki persentase terbesar terdapat pada pembayaran yaitu sebesar 91,20 persen, yang artinya metode pembayaran yang diterapkan efektif. Komponen tempat yang memiliki persentase terbesar yaitu jangkauan transportasi sebesar 94,00 persen. Hal ini menunjukkan bahwa bagi konsumen agroindustri Askha Jaya memiliki kapasitas yang baik dalam luas area agroindustri dan jangkauan transportasi. Promosi yang dilakukan agroindustri Askha Jaya bagi konsumen sangat membantu dalam memperoleh produk yang ditawarkan yaitu sebesar 89,60 persen.

Berdasarkan keempat komponen diperoleh nilai rata-rata di atas 80 persen yang masuk dalam kategori baik dan komponen yang mendominasi yaitu pada komponen produk yaitu sebesar 91,77 persen, yang artinya bagi konsumen produk keripik pisang agroindustri memiliki keunggulan yang baik dalam kualitas maupun kuantitas. Hal ini sejalan dengan penelitian Wantini, Martono dan Hindrayani (2013) yang mengungkapkan bahwa produk berpengaruh terhadap keputusan pembelian konsumen.

\section{Kendala-Kendala yang Dihadapi dalam Menerapkan Bauran Pemasaran}

Kelangkaan bahan baku pisang yang mengakibatkan produk keripik pisang tidak tersedia dalam jumlah banyak, sedangkan permintaan konsumen terus meningkat. Hal ini mengakibatkan naiknya harga jual produk dan daya beli konsumen berkurang.

Jumlah konsumen yang ramai pada waktu tertentu, membuat karyawan kewalahan dalam melakukan pelayanan. Tidak sedikit konsumen yang terburuburu dalam menginginkan produk dalam ukuran tertentu. Kemasan produk ekonomis sering menjadi kendala, dikarenakan ukuran produk kemasan yang tersedia pada rak penjualan tidak beragam, sehingga memakan banyak waktu untuk proses pengemasan produk dalam pelayanan terhadap konsumen. Kendala lainnya terdapat pada pemasaran online, waktu pengiriman yang kadang terhambat, produk terkadang hancur selama berada dalam perjalanan yang membuat konsumen kurang puas, hingga adanya pihak-pihak yang tidak bertanggungjawab mengambil foto produk agroindustri tanpa izin.

\section{Bauran Pemasaran yang Sebaiknya Dilakukan}

Agroindustri Askha Jaya telah menerapkan bauran pemasaran dengan baik. Namun masih terdapat kendala-kendala. Oleh karena itu, agroindustri Askha Jaya membutuhkan bauran pemasaran yang sebaiknya dilakukan guna mempertahankan dan meningkatkan usaha agroindustri.

Sebaiknya agroindustri Askha Jaya melakukan perluasan daerah untuk memperoleh bahan baku pisang yang lebih banyak, sehingga meminimalisir kelangkaan produk. Selain itu, pada saat terjadi kelangkaan produk sebaiknya agroindustri mengurangi sedikit ukuran berat produk keripik pisang dan sedikit menaikkan harga jual. Hal ini dilakukan guna mempertahankan pangsa pasar dan mempertahankan daya beli konsumen. 
Sebaiknya agroindustri Askha Jaya menambahkan label harga pada setiap rak produk yang ada di dalam outlet penjualan. Hal ini dimaksudkan untuk mempermudah konsumen dalam pemilihan produk tanpa harus menanyakan tiap harga produk kepada karyawan, sehingga proses pembelian akan lebih mudah dan efektif untuk konsumen, khususnya konsumen yang terburu-buru dalam menginginkan produk dapat lebih cepat melakukan sistem pembayaran.

Produk keripik pisang kemasan ekonomis yang tersusun pada rak-rak penjualan hanya produk yang dikemas pada ukuran 250 gram. Saat kunjungan konsumen ramai, tidak sedikit konsumen yang menginginkan produk dikemas dalam berbagai ukuran. Sebaiknya agroindustri menambah ukuran kemasan lainnya pada rak penjualan, seperti ukuran 500 gram dan $1 \mathrm{~kg}$. Hal ini dimaksudkan untuk mempermudah karyawan dalam pelayanan kepada konsumen yang menginginkan ukuran-ukuran tersebut, sehingga meminimalisir waktu dan mempercepat proses pelayanan.

Pengiriman produk secara online yang memanfaatkan jasa pengiriman produk sangat berisiko. Sebaiknya pada proses pengemasan produk yang akan dikirim, perlu ditambahkan pelindung tambahan di dalam box atau kardus, sehingga meminimalisir terjadinya produk patah atau hancur. Media sosial yang digunakan untuk pemasaran online seperti Marketplace sebaiknya ditambahkan catatan khusus seperti peringatan pemberian sanksi terhadap pencurian foto atau gambar produk tanpa izin agroindustri. Hal ini dimaksudkan untuk menghindari hal-hal yang dapat merugikan Agroindustri Askha Jaya oleh pihak yang kurang bertanggungjawab.

\section{KESIMPULAN}

Bauran pemasaran pada agroindustri Askha Jaya sudah diterapkan dengan baik, dengan memanfaatkan teknologi yang ada sehingga produk dapat dijangkau oleh konsumen di berbagai daerah. Kendala-kendala yang dihadapi dalam menerapkan bauran pemasaran yaitu kelangkaan bahan baku, naiknya harga jual produk, proses pelayanan konsumen yang terhambat pada saat kunjungan ramai, lamanya waktu jasa pengiriman yang mengakibatkan produk hancur dan adanya pengambilan foto produk tanpa izin pada pemasaran online. Bauran pemasaran yang sebaiknya diterapkan mengurangi berat ukuran produk dan sedikit menaikkan harga jual, perlu adanya penambahan label harga pada kemasan dan rak penjualan serta penambahan ukuran kemasan yang beragam untuk mempermudah sistem pembelian, perlu adanya pelindung tambahan pada box pengiriman barang dan perlu adanya pemberian sanksi pada pemasaran online untuk menghindari hal-hal yang dapat merugikan agroindustri.

\section{DAFTAR PUSTAKA}

Akbar TR, Lestari DAH, dan Nugraha A. 2020. Analisis bauran pemasaran, risiko dan kinerja keuangan agroindustri Kopi Bubuk Cap Obor Mas Lampung, di Kecamatan Kotabumi Kota, Kabupaten Lampung Utara. 2020. Jurnal Ilmu Ilmu Agribisnis, 8(1): 78-85. https://jurnal.fp.unila.ac.id/index.php/JIA/artic le/view/4345/3118. [12 Desember 2020].

BPS [Badan Pusat Statistik]. 2018. Statistik Tanaman Buah-buahan dan Sayuran Tahunan Indonesia 2018. Badan Pusat Statistik. Jakarta.

Direktorat Jenderal Hortikultura. 2018. Luas Panen Buah-buahan di Indonesia. https://www.pertanian.go.id/home/?show=pag e\&act=view\&id=61. [09 Oktober 2019].

2018. Luas

Panen Pisang dan Produksi Pisang Menurut Provinsi 2014-2018 https://www.pertanian.go.id/home/index.php? show=repo\&fileNum=311. $\quad[09$ Oktober 2019].

Kementerian

2020. Kebijakan Pertanian. http://hortikultura.pertanian.go.id/?kebijakan. [10 September 2020].

Epriani M, Endaryanto T, dan Indriani Y. 2017. Sikap konsumen dan strategi pemasaran dua merek kopi bubuk di Kota Bandar Lampung. Jurnal Ilmu Ilmu Agribisnis, 5(4): 414-421. http://jurnal.fp.unila.ac.id/index.php/JIA/articl e/view/1751/1554. [05 Agustus 2020]

Indriastuti I, Affandi MI, dan Indriani Y. 2015. Strategi pemasaran berdasarkan perilaku pembelian keripik pisang di Kota Metro. Jurnal Ilmu Ilmu Agribisnis, 3(2): 114-121. https://jurnal.fp.unila.ac.id/index.php/JIA/artic le/view/1029/934. [05 Agustus 2020]

Kotler P. 2002. Manajemen Pemasaran Jilid 2. Edisi Milenium. PT Prenhallindo. Jakarta.

Ledy DS, Haryono D, dan Situmorang S. 2019. Analisis bauran pemasaran (marketing mix) dan strategi pengembangan: studi kasus pada agroindustri Kopi Bubuk Cap Intan di Kota Bandar Lampung. Jurnal Ilmu Ilmu 
Jurnal Ilmu Ilmu Agribisnis: Journal of Agribusiness Science, 9(4), November 2021

Agribisnis, $\quad$ 7(1): 52-59. https://jurnal.fp.unila.ac.id/index.php/JIA/artic le/view/3331/2552. [08 Desember 2019]

Mantra IB. 2004. Demografi Umum. Edisi Kedua. Pustaka Belajar. Yogyakarta.

Mustafa H. 2000. Teknik Sampling. http:home.unpar.ac.id/-hasan/sampling.doc. [04 November 2019]

Putri VD, Affandi MI, dan Nikmatullah D. 2020. Analisis kepuasan konsumen dan bauran pemasaran pada agroindustri kopi bubuk Cap Jempol di Kota Bandar Lampung. Jurnal Ilmu Ilmu Agribisnis, 8(1): 132-136. https://jurnal.fp.unila.ac.id/index.php/JIA/artic le/view/4346/3119.[12 Desember 2020].Sufren dan Natanael, Y. 2014. Belajar
Otodidak SPSS Pasti Bisa. PT Elex Media Komputindi. Jakarta.

Sugiyono. 2010. Metodologi Penelitian Administrasi. CV. Alfabeta. Jakarta.

2011. Metode Penelitian Kuantitatif, Kualitatif dan $R \& D$. Afabeta. Bandung.

2011. Statistika untuk Penelitian. Hlm. 74. Alfabeta. Bandung.

Wantini S, Martono T, dan Hindrayani A. 2013. Pengaruh bauran pemasaran terhadap keputusan pembelian emping melinjo di Kelurahan Ngadingrejo Kecamatan Kartasura. BISE, $\quad 1(1)$ : 67-79. https://adoc.pub/queue/pengaruh-bauranpemasaran-terhadap-keputusan-pembelianempin.html. [10 September 2020]. 